\title{
Protecting our environment: The need for South African youth with a mission and black consciousness
}

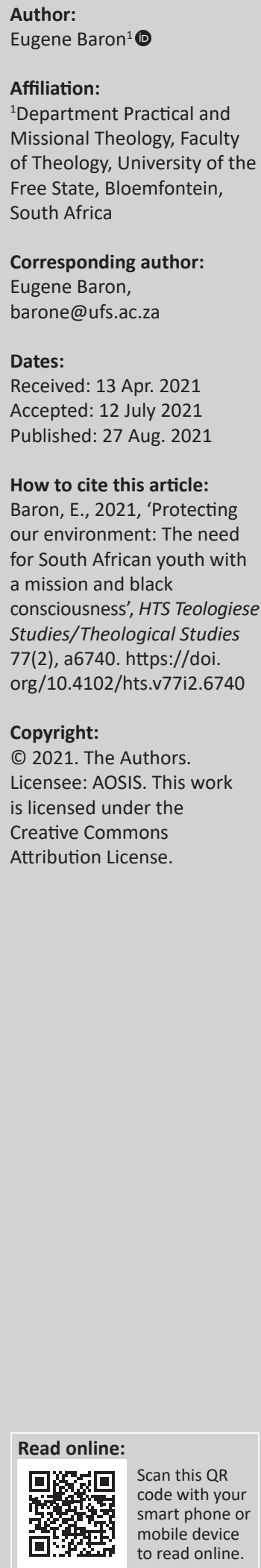

Christianity has contributed to environmental degradation. In terms of their role, the church youth are ipso facto part of such a contribution. However, an eco-theological diagnostic analysis cannot interpret the role of youth, especially black youth, through the same lenses. From a Black theological perspective, black youth's role should be interpreted and discussed in terms of what Fanon and Biko describe as 'self-hatred' and the need for black consciousness. It is such self-hatred that gives rise to environmental degradation that is not articulated within various eco-theologians' strategies towards care for the environment in a neo-colonial context in South Africa. The article argues that such a deficiency in eco-theological literature needs some attention to address the future black youth's contribution to a friendlier environment. The author therefore suggests a 'missional consciousness' for one of the strategies for black youth in the quest for the black youth's participation in environmental care.

Contribution: This article contributes to the broader discourses on ecotheology. It affirms the contributions on human beings' role towards the environment, but further highlights the inequality among human beings in neo-colonial context and how ecotheology should approach the ecological crisis with consideration to such a context. Therefore, the contribution brings into dialogue the post-colonial discourse, specifically the discourse of black consciousness, in relation to a missional consciousness in resolving the ecological crisis through the participation of church youth. Ecotheology has not specifically considered the notions of 'missional consciousness' and 'black consciousness' in its discourse on protection of the environment. The author relates this discussion specifically to church youth.

Keywords: environmental care; black youth; missio Dei; missional consciousness; black consciousness.

\section{Introduction}

The agency of the church youth has most often been limited and expressed in terms of congregational involvement (cf. Baron 2019). In terms of the old missionary paradigm, one of the key objectives was that the youth should - as a particular focus of the Protestant churches grow spiritually and not become too politically conscious or fulfilling the missio Dei also in the communities. This would imply that youth do not become co-opted into socio-political activities if not exclusively evangelistic in nature. ${ }^{1}$ This has also been the way in which Christianity has for decades articulated mission, the church and the environment - the latter to be a means to an end for the church. Ross (2018) articulates this well:

There is a widespread view in mission circles that the environment is at best a contemporary opportunity for mission, in that it provides an evangelistic 'hook' to touch people's deepest fears and then present them with 'the gospel' and what we believe mission should really focus on is 'introducing individuals to the living God'. (p. 6)

Baron (2017) also argues that church youth should have more than such a limited or exclusive role as God's agents in the world, but should be one of the agents of transformation within the urban and broader societal contexts. Nel (2015:548) also emphasises the activist role of church youth in society during the heydays of apartheid in South Africa. He makes reference to 'South African

1.Smith (2002) refers to his experience and training within the old missionary paradigm that did not make people conscious of the mission of God that is also to be on the 'streets' (activism).

Note: Special Collection: Youth, Faith, Climate Change and Environmental Consciousness: A Case for Sustainable Development, sub-edited by Jacques Beukes (University of Pretoria), Juliane Stork (Humboldt University, Berlin) and Ignatius Swart (University of the Western Cape). 
Black Theology' that 'pleaded for a Christian presence in the Struggle' during the period prior and during the 1976 youth uprising in various parts of South Africa and the later boycotts of the 1980s that were mainly led by the Black Consciousness Movement with Steve Biko as one of the main influencers. It was mainly young people in the schools who went to the streets to urge for social transformation, and in terms of such a role the church and church youth were challenged to join the struggle for freedom.

However, although this point has been made to make churches aware of the immense contributions that church youth can make to society, it would not mean much if the church does not commit itself to cultivate what Baron (2019) refers to as a 'missional consciousness' ${ }^{2}$ particularly among Black church youth in South Africa. Therefore, the author argues in this article that the notion of 'missional consciousness' is directly related to the notion of Black consciousness as it stresses the importance of church youth in the 'black' communities to become conscious of themselves as valuable participants of God's mission on the earth. The question could be posed: In what way does the Christian faith play a role in black consciousness-making in South Africa as a precursor to practices and actions to address the challenge of environmental care?

The well-known black consciousness movement was such a movement that called for blacks to 're-appreciate themselves'. The black consciousness movement could be aligned with the notion 'missional consciousness' ${ }^{2}$ as far as appreciating one's (though particularly black people) value in terms of the missio Dei. Baron (2019) argues that a 'missional consciousness' is necessary where predominantly black members ${ }^{3}$ in the benches of churches do not appreciate their intrinsic value and contribution that they can make in the missio Dei. In the old missionary paradigm, 'white' missionaries became the epitome of what it means to be set apart to do God's work, and this was internalised by black church members. The notion is not only based on the idea that you are valued, but also your contributions, and that black people are also agents of the triune God. This should be understood within Bosch's (1991:467) discussion of 'Mission as Ministry by the Whole People of God'. Therefore, the author argues that some of the strategies to address environmental degradation are not only practices to care for the environment or the education thereof, but at its heart is cultivating a 'missional consciousness' of black church youth that would also translate into their care for the environment. The notion 'missional consciousness' would as previously argued be placed in relation to the black consciousness thought in South Africa, especially because in the South African context oppression and marginalisation of blacks were normalised and internalised by various blacks (including youth) and continued in various sectors of

2.This notion is borrowed from the author's previous work entitled, "The Call for African Missional Consciousness Through Renewed Mission Praxis in URCSA', African Missional Consciousn published by the journal Studia Historiae Ecclesiastiae 45(3), 2019. The notion missional consciousness throughout the paper is borrowed from Baron's (2019)
previous work in this regard.

3.Baron is reflecting on the Uniting Reformed Church in Southern Africa (URCSA) in his research that is predominantly people of colour, and a former mission church. society. Cone (1997:36; cf. Spencer 2008:289) argues that there is no 'universal language' in Theology, only an interested language. In terms of his argument, 'theology always develops, within a particular context and social setting'. Therefore, this article is to say that an ecotheology should also address the black consciousness of church youth if it wants to address the challenge of environmental care in neo-colonial contexts. Cone (2000) argues that:

$[T]$ he logic that led to slavery and segregation in the Americas, colonization and apartheid in Africa, and the rule of white supremacy throughout the world is the same one that leads to the exploitation of animals and the ravaging of nature. (p. 36)

\section{Therefore, his subsequent argument follows:}

People who fight against white racism but fail to connect it to the degradation of the earth are anti-ecological, whether they know it or not. People who struggle against environmental degradation but do not incorporate in it a disciplined and sustained fight against white supremacy are racists - whether they acknowledge it or not. The fight for justice cannot be segregated but must be integrated with the fight for life in all its forms. (Cone 2000:36)

It is therefore also important for Cone (2000:37) that it is not either or, but that those that are caring for the environment should also take the black consciousness ideology as an ideological instrument in the neo-colonial context that could be crucial to address environmental degradation. The author will argue in this article that cultivating a missional consciousness will assist with the challenge that the Black Consciousness Movement articulates: 'Black is Beautiful'. It argues that this would be an important missional strategy to engage the youth and to protect the environment.

\section{Mission strategies for environmental care}

Scholars such as Nche, Achunike and Okoli (2017:173) would for instance argue that what is needed for the church in Nigeria is to utilise its liturgy and sermons to make its members aware of environmental degradation, to reflect also on its own culpability by investing in businesses, 'living luxurious and unfriendly lifestyle and consuming patterns' that have a negative effect on the environment et cetera. One wonders whether a focus on action or inaction and addressing the issue from a pragmatic stance would not be too short-sighted for a country like South Africa that has been experiencing colonialism and that too of a special type (apartheid). The aforementioned is part and parcel of the history of South Africa and should be taken into account when diagnosing or addressing the 'why' of action or inaction in terms of the protection and care for the environment. In fact, if it were to be an issue of only action and inaction, then we would in South Africa still have to deal with the 'colonisation of the mind' that is the root cause of the self-hatred of black people. For instance, Ramantswana (2016:187) stresses the effects of 'black-hatred' even in Biblical interpretation by black scholars, 'The colonisation of the African mind turned the Black epistemically 
white by making blacks turn against their own institutions and knowledge systems, thereby regarding them as primitive'.

Another strategy to address the challenge of environmental degradation is that of the sharing of information or awareness campaigns. However, Conradie argues that the fact that people are aware of the disastrous effects of their actions on the environment does not mean they would necessarily be deterred. Therefore, for him, the connection between 'the more you know the more you will be deterred' is a fallacy. Conradie (2011) states:

The underlying problem is clearly not just a lack of information or planning. It is a liberal fallacy to assume that information and education is in itself the answer to moral action. (p. 5)

There is also another strategy that Ross (2018:5) proposes, which has to do with interfaith collaborations. He argues that to build on the mutual recognition of God as the creator would also encourage people from different faiths to work towards environmental care. It seems that the strategy of Ross is bigger than not only environmental care strategies, but also serves as a strategy towards an increase in interfaith dialogue and partnership. She argues that the shared belief in one creator will form a 'solid foundation for building good relationships that can help enormously in dealing with more sensitive differences between faiths' (Ross 2018:5). In this manner, Ross does bring into conversation the relationship between environmental care and that of human beings and their relationships with one another to indicate that interpersonal relationship is the key for a conversation and strategy on environmental care.

\section{The environmental challenge for Christianity: A problem of the black 'soul'?}

In a cursory review of the role of church youth in terms of environmental destruction, not much academic articles pop up as if the youth - by being members of the church (ipso facto) - are by default included in the call for churches to address ecological destruction. ${ }^{4}$ Therefore, the author will now in very broad strokes discuss the contribution of Conradie in terms of his and other eco-theologians' diagnostical analysis of the contributions of Christianity in ecological degradation - in part to determine also to what extent the youth are guilty of environmental degradation. The discussion would be limited as it would discuss it through the lens of black experience(s) in South Africa and the contribution of Christianity on the degradation of the environment. The question would be: Do eco-theologians make such a link?

Conradie (2011:5) argues that Christianity should also bear the guilt for the environmental crisis and concur with Lynn White's thesis that the notion of 'dominion' over nature was part and parcel of the approach of Western science that the

4.For instance, the journal Missionalia has less than eight articles on ecology and mission, and none of it explicitly addresses the role of the Christian Youth as agents mission, and none of it explicitly addresse
of God in protecting the environment.
Judeo-Christian tradition embraced. Therefore, White subsequently argues, 'Christianity is the most anthropocentric religion the world has seen' (cf. Conradie 2011:5). Conradie also points to the counter arguments of other apologists of Christianity and their arguments that - if Christianity is interpreted adequately it would not only be the cause of the environmental crisis, but part of the solution also - one cannot ignore the contribution that Christianity has made towards the steep increase of global warming, and other ecological challenges that the world has to face. For instance, in terms of Christians' passion to conduct evangelistic work, they have contributed to carbon emission footprints through local and international air travel and commuting by car, to and fro, when being part of evangelistic outreaches. ${ }^{5}$ This is but some of the myriad examples that could be cited. John Paul II (1995:65) asserts in his 1995 encyclical, namely the 'The Gospel of Life', that there is a distinction between human beings and the rest of creation when he writes:

Everything in creation is ordered to man and everything is made subject to him ... [A]nimals and plants ... receive only the 'faintest glimmer of life' compared with 'the sublime dignity of 'the crown of creation (us)'. ${ }^{6}$

We also take note of the words of Delio (2008:78) when he argues that: 'At its deepest root, our ecological crises derive from our belief that humans are somehow above or fundamentally distinct from - indeed, absolutely superior to, the rest of creation'. These above accounts illustrate that Christianity was at least responsible for creating a hierarchy in God's creation with human beings at the helm of it.

However, Conradie (2011:7) shows that despite the guilt of Christianity (mainly its notions of domination et cetera), there were genuine attempts at restoring, or what he refers to as 'reforming', Christianity - to regard nature as part of the oikos - the whole household of God. This is indeed a valuable perspective. The notion of oikos is also posited by DeWitt. He describes the notion with reference to a metaphor of 'economy wheels', namely a small one (wheel) representing the human economy and the larger wheel the Creation's economy. He argues that the human economy (smaller wheel) should function within the larger Creation's economy. He (DeWitt 2008) states:

The wheel of Eden - the economy which Adam and Eve were appointed stewards - was a wheel moving harmoniously within a wheel; Eden's economy cycled in harmony with God's creation. When it operates outside of Creation's Economy, degradation results. (p. 86)

Therefore, this was an attempt to address the former guilt of the construction of a hierarchy in God's oikos (household). The point is that human beings should understand that there is no distinction between them and the rest of God's creation. We can make more or less the same connection in the

5.During the outbreak of the coronavirus pandemic, churches and congregations were left with no choice, especially during lockdown in South Africa to pursue online evangelistic strategies.

6.https://www.vatican.va/content/john-paul-ii/en/encyclicals/documents/hf_jp-ii_ enc_25031995_evangelium-vitae.html 
response of DeWitt (2008:88), because it seems for him that the problem lies in-between the arguments of the Christian (human beings) and the environment. Alluding to the Genesis 2 narrative, he refers to human beings' (Adam's) reciprocal relationship as the 'gardener' with the 'garden' between the 'biosphere and its human safeguards'.

This whole study that focusses on what is termed the anthropocene in ecotheology is to articulate the central focus on human beings and their interest as a sin. The challenge with the former formulation would be: the equation of all human beings as if there was not a history of colonisation - a world that created the inequality of human beings - of which Christianity also contributed. ${ }^{7}$ Therefore, the discussion on human beings in opposition to nature is a valuable and appropriate argument but not without its limitations. This is not to deny the fact that in most instances, human beings were mostly concerned with their own well-being than that of the rest of creation.

However, what if black youth do not appreciate themselves in relation to the rest of God's creation? Then a further, deeper appreciation for the oikos would merely not suffice because there is a need for a black ontological discourse. This should be an important focus in a country wherein most black people have lost their human dignity. This should be especially understood in terms of Stubbs (1978) assertion that black people should at first regard themselves not in relation to 'white' and other subsequent norms of what is beautiful, moral and good but look at themselves - first and foremost - of what is good and valuable and being created in God's image. Though implicitly Conradie would include all human beings as part of the oikos, the problem is that because of the extended period of subjugation, oppression and marginalisation, it could not be regarded as a naturally consequential link for black people to appreciate themselves with the rest of the oikos.

However, in another contribution, Conradie (2011:11) does address the issue of cultural goodness that could be meaningfully utilised for the above argument, but it comes also with its own limitations. In his chapter entitled 'Local Christian Communities can make a major contribution to earth keeping', he refers to the problem as a 'cultural crisis' where 'the values underlying the dominant cultural and economic practices in the world today have become bankrupt' (Conradie 2011:13). He describes the environmental crisis also as a sign of the loss of a 'spiritual dimension'. The issue of the 'cultural' and 'spiritual void' speaks to the challenge of consciousness. For Patriarch Bartholomew and Pope John Paul II, there is a need for a renewed view 'about ourselves' especially 'from the perspective of the divine design for creation'; therefore, he concludes that, in addressing ecological degradation, a radical change is needed in the inner heart, which then will translate into a change in our lifestyle as well as

7.See particularly the work of Elphick (2012) "The equality of Believers. Protestant Missionaries and the Racial Politics of South Africa' in which he argues that the Missionaries and the Racial Politics of South Africa' in which he argues that the
challenge during colonialism and apartheid in South Africa is that of equality and challenge dur
inequality. 'unsustainable patterns of consumption and production'. However, for them this change happens after a 'genuine conversion in Christ' which will 'change the way we think or act' in terms of ecological degradation and the protection of the environment (Cf. Conradie 2011:13).

It is important to note that the reference of the Pope is not only on 'one another' but also the 'view of ourselves'. Another instance is the words of Ahmed Djoghlaf at the Bali meeting on Climate change in December 2007 in which he also deals with the question on environmental degradation on a personal, consciousness level. He states:

In my view there are three ways to reach people: through their wallets, their wealth and their soul ... the first two are certainly current; the third has yet to be achieved. (cf. Conradie 2011:13)

The above indeed provides clear signs of the need for a 'conversion of the mind', as part of a strategy of addressing ecological degradation. His references above to 'cultural' and 'spiritual loss' speak of an inherent issue of personhood. However, in another contribution, Conradie argues therefore that a 'new kairos' (which Conradie might have at the back of his mind the Kairos Document [KD] that addressed racial segregation in South Africa) is needed. According to Conradie, this 'new Kairos' is called for in which ecological concerns could be squarely addressed by the church (cf. Conradie 2011:8). ${ }^{8}$ His point of argument is well taken, but one wonders whether the need for a second 'kairos' will not be a prophetic appeal that will become a diluted version of the previous call for the rejection of a racial consciousness which was at the root of the first KD in South Africa. It is at this intersection where the author argues that the 'spiritual dimension' and the 'black consciousness' cause will have to play its role. ${ }^{9}$ Nothwehr (2015:89) makes the connection between human beings. However, it is stated in relation to the rest of the oikos, with a specific focus on the 'poor'. He argues that the well-being of the land cannot be divorced from the 'spiritual and the material well-being of the people of Israel' because the God of Israel was interested in the restoration of the land in relation to the poor (Leviticus 25:23) (Nothwehr 2015:89).

Though Nothwehr and Conradie do allude to the ideals of the 'Black Consciousness Movement', it should be made more explicit: they appreciate black people of their intrinsic value for themselves as a crucial ideal of Christianity to restore the environment. This is what Pope John Paul II argues that in solving the ecological crisis, it is vitally important in terms of: '.. how we view ourselves ...' ${ }^{10}$ The issue cannot only lie between a Christian and the youth

8.Conradie (2011:8) states, "David Field adds that confessing Christ in response to the ecological challenges poses a new "Kairos" for the church in South Africa, a challenge similar to the ones posed by Nazism in Germany and apartheid in South Africa'.

9.See also the argument of James Cone later in the article that one cannot make an appeal for the restoration and protection of the environment without addressin appeal for the resto also the restoration of the human dignity of marginalised and oppressed people. He states, 'While white racism must be opposed at all cost, our opposition will not be effective unless we expand our vision. Racism is profoundly interrelated with other
evils, including the degradation of the earth' (Cone 2000:38).

10.See the declaration on the environment signed by Patriarch Bartholomew and Pope John Paul II on 10 June 2002. 
(as this article would argue) for that matter and their appreciation for the environment - but also within themselves, and their 'black selves' in relation to the 'white' selves. Themselves and the socially constructed 'betterselves' that history told them depend on pigmentation. The focus should be on the personhood, particularly also 'black' personhood, in addressing environmental degradation.

However, it has also been argued within literature that the environment should not be dealt with as a means to an end, but as its intrinsic value that it has. It should not be studied in terms of what it can benefit human beings, but that in itself has intrinsic value. This argument would be close to what the author argues in this article that the same logic that has been used for in terms of the care for the environment (rest of creation), the same must also be advocated for in terms of the way certain human beings have been treated as non-human beings. ${ }^{11}$ Spencer (2008:289) cites the words of Dorceta Taylor mapping out precisely what would be the problem with some of the overgeneralisations of the notion 'human' in the ecotheology discourse and that the 'we' is mostly the 'white' we. Therefore, she states the difference with the 'black' we, '... one of the enduring struggles of people of color is that of self-determination - the struggle to define who they are and how they interact with the land', is indeed a case of 'black consciousness' (Spencer 2008:289).

\section{Christian youth, black consciousness and self-hatred}

Why is it important to focus in South Africa on 'black consciousness' in the task to address environmental care? The answer would lie with the manifestation of self-hatred among black Christian youth in South Africa. The wellknown black consciousness movement was such a movement that called for blacks to 're-appreciate themselves' in the context of what Fanon (Algeria) and Biko (South Africa) describe as the pathology of self-hatred. We have seen in the not too distant past the violence and often destructive manner in which black youth have been caricatured in the media. Often, the destruction of their own places and spaces of education, worship, public buildings and infrastructure in the name of revolutionary ideals is dominating the media reports. The question that could be framed in terms of the care of the environment could be: why does the youth not appreciate the earth's resources, as DeWitt (2008:88) states: 'We know from experience that gardens (and the biosphere) serve us - with good food, beauty, flavourful herbs, useful fibre, healing remedies, pleasant microclimates, soilmaking, nutrient processing, and seed production?' For the author, the answer lies both in what the Black Consciousness Movement provides us with 'black is beautiful' and the notion missio Dei - that all of creation is participants with God in restoring the shalom of the earth. This relates directly to the notion of 'missional consciousness'.

11. See Cone's argument that the same logic that is used to degrade the earth is the same logic used to degrade black lives.
In the work of Fanon (1990) ${ }^{12}$ and Stubbs (1978), ${ }^{13}$ it is argued that black people have always compared themselves to white people, and therefore have created a 'self-hatred' for their own skin, their own environment and spaces. It was internalised self-hatred in black people that has evolved because of comparing themselves to all that is 'white' which was regarded as perfect and the norm of what is good, and aesthetically pleasing. Therefore, Biko was against the terms that the white, apartheid government in South Africa used when referring to blacks as non-whites, almost as if white is the norm against which blacks should always strive themselves to be. In his address entitled 'Concerning Violence', Fanon describes in detail the internal psychological despisement of black lives and how colonialism has created within black people themselves a hatred for themselves, and all that is black (Fanon 1990). Baloyi (2020:1) also argues that 'black-hatred is impeding our own decolonisation', and that 'as long as such pathology continues colonialism and neo-colonialism will succeed'. Baloyi (2020:1) attributes this to the loss of the slogan of Biko's 'Black is Beautiful' ideology (black consciousness) that does not 'resonate among the black masses today' and therefore the manifestation of self-hatred. Baloyi (2020) states:

As much as people can blame the slow pace of the transformation agenda in South Africa, it is equally important to determine the role of inflicted self-hatred as a factor in the process. (p. 1)

Can we make this link in eco-theological discourse? The discussion of Conradie (2011:5-8) on the role that Christianity has played over the years includes the notion of 'exploitation' and 'domination', which finds prominence in the doctrinal statues of churches globally. Therefore, the following is important: 'Mission would include demonstrating to people the integrity of creation and their own integrity as part of it' (Loader 1991:55). However, the discussion of Loader resonates strongly with Bosch's (1991) assertion of a new emerging 'postmodern' mission, which includes the issue of 'domination' previously at the forefront of mission work and the motif for missionaries. When Tucker and Grim (eds. 2000:xix; cf. Conradie 2011:12-13) responded to the role of religion in creating environmental consciousness, they do so in very broad terms; for them it is a 'moral and spiritual crisis'. They argue that it is one's religion that also shapes our 'attitudes towards nature in both conscious and unconscious ways', but our religion also contributes to our understanding of 'ourselves as creatures of nature'. What is important is their following assertion, 'Religion provides basic interpretative stories of who we are, what nature is, where we have come from, and where we are going ...'.

The assertion of these scholars is appropriate, but one, once again, wonders whether the well-articulated religions, especially in the South African context, would be able to fulfil such a role without simultaneously dealing with the imprints of apartheid on the youth. Does the story of appreciation also not equally address the re-appropriation of good stories of 'black lives' and how adequately had this been addressed?

12. His work published in French in 1952, 'Black Skin, White Masks' and in 1961 'The Wretched of the Earth'.

13. See the collection of Steve Biko's addresses in the book 'I Write What I like' that was published after his death. 


\section{The role of the church in the process of self-appreciation of youth}

The church can in no way stand aloof in the context of the self-hatred of youth but should fulfil the role of God's agents in the world to both restore the youth's appreciation of themselves by cultivating a 'missional consciousness'.

Biko alluded to the contribution of Christianity during apartheid, specifically within its missionary architecture that has been promoting self-hatred. ${ }^{14}$ Stubbs (1978:59) argues that the church is also a social institution. Therefore, it has to speak to the social realities that people are faced with, and this is always the intention of the institutions such as the church and therefore he argued 'in most cases religion is intertwined with the rest of the cultural traits of society'. Nevertheless, the problem comes when it is far removed from the 'culturalmake-up' of the society that it is part of - because then 'disgruntlement (from society) steps in'. He argues further that this is what happened when Christianity landed in the Cape, people were required to abandon their culture and had to get accustomed to new customs, etiquette and people had to 'cast away their indigenous clothing, their customs, their beliefs which were all described as being pagan and barbaric' (Stubbs 1978:60). This was all done in the name of Christianity and the Bible. In terms of Biko's account, 'the Africans gave way to those who know the religion at best' and in the process lost their own dignity and humanity and value themselves and their own culture. The Christians from Western Europe did not only tell them about God, but 're-arranged their social and cultural life in the name of Christianity'. In his address in 1972, he states:

In a country teeming with injustice and fanatically committed to the practice of oppression, intolerance and blatant cruelty because of racial bigotry; in a country where all black people are made to feel the unwanted stepchildren of a God whose presence they cannot feel; $\ldots$ the Church further adds to their insecurity by its inward-directed definition of the concept of sin and its encouragement of the mea culpa attitude ... Because the white missionary described black people as thieves, lazy, sex-hungry etc., and because he equated all that was valuable with whiteness, our Churches through our ministers see all these vices I have mentioned above not as manifestations of the cruelty and injustice which we are subjected to by the white man but inevitable proof that after all the white man was right when he described us as savages.

However, how do we make the connection between selfhatred, and our responsibility to care for the environment? The apartheid's re-arrangement of society was not only to devalue black, but also caused self-hatred among black people and their own communities. Whatever was owned by black, their spaces, including environmental spaces, became despised. Black people were geographically located in almost all towns and cities in close proximity to the waste-dumps, or industrial waste sites, whereas whites were residing on the opposite side of the town: the greener, well-maintained (by municipalities) geographical areas, etc. For example, within the context of the United States of America, we read in the media that during Covid-19 pandemic, such racial-geographical and demographics were exposed:

Decades of proximity to pollution have compromised neighbourhood air quality and the respiratory health of the communities and this may have played a role in how they are affected by the coronavirus pandemic.... Recent evidence linking air pollution exposure with COVID-19 mortality risk thus indicates direct links among environmental racism, air quality and disproportionate death rates for Black and Indigenous communities.... (Lei Win 2020)

Cone (2000) makes reference to 'the United Church of Christ Commission of Racial Justice's report in 1987' that found:

[F]orty percent of the US's commercial hazardous waste landfill capacity was in three predominantly African American and Hispanic communities. The largest landfill in the nation is found in Sumter County, Alabama, where nearly seventy percent of its seventy thousand residents are black and 90 percent are poor. (pp. 39-40)

The question is now: how do we suddenly concentrate as a church on 'care for the environment when black people were not allowed to think in terms of the apartheid geographical and demographical arrangement of themselves as being "'morally" good and "appreciative" citizens', and subsequently also think of their environment as part of God's creation to appreciate?

In fact, Bunyan Bryant argues that 'environmental racism' is actually 'an extension of racism'. According to him, one cannot ignore the decisions that are made by governments of where 'toxic and hazardous waste will be dumped' and that this is reflected in 'institutional rules, regulations, and policies of governments'. Environmental racism is where the communities of colour have been systematically excluded from the 'environmental decisions' that affect them directly and the 'disproportionate exposure' of mainly their communities to the toxic and hazardous waste (Cone 2000:40).

These and other examples of environmental racism would indeed have an effect on how young black people will think about themselves as part of God's creation (black and missional consciousness). This self-hatred should be restored. There should be an attempt to engage with the protection of the environment by emphasising the nexus between youth, black consciousness, missional consciousness and protecting the environment.

The strategies that Nche et al. (2017:173) suggest could be used, such as preaching, worship and prayers and education of church members (as earlier stated), as well as Conradie's notion of the appropriation of an oikos theology, but it would not come to fruition when there is indeed not a self-love and an appreciation of blacks for themselves as a result of discovering their value and role in God Kingdom, and dealing with the self-hatred.

It is important to place an emphasis more on the 'missional consciousness' of church youth within black communities in 
South Africa to address the issue of environmental degradation. It is important among all other interventions of environmental care to emphasise that when youth (including church youth) will begin to appreciate themselves as God's agents within their blackness- it will also contribute to the broader strategies for environmental care. A 'missional consciousness' would mean that church youth in black communities would regard themselves as the stewards of God in all things which they possess (cf. DeWitt 2008:85). Therefore, more is needed than only an awareness of the destruction of the environment and means to care for the environment but also a project on establishing a 'consciousness' specifically a 'missional consciousness' that would allow black people to re-position themselves in the 'household of God' (cf. Conradie 2011). The framing of the question of church youth in black communities and the protection of the environment are part of the discussion on the role and positioning of the ekklesia in terms of God's mission (missio Dei). In framing the role of the church, as such, it would indeed mean that the role of the youth cannot be regarded as a responsibility not because they are commissioned by the church but because they are agents of God. As a missional strategy, therefore, it would be important to see themselves fundamentally as God's agents. The church would have to articulate such a task and responsibility of the youth, which would have to translate into a 'missional consciousness'. This by implication would mean that the youth would begin to see themselves also worthy of being God's agents in the world, which is a process of introspection and selfappreciation. In terms of this role, the cleavage between what is valuable (that was previously far removed from their understanding of themselves) should be nurtured, cultivated within the church as a core task should it in any way want to address and encourage any youth to become involved in the care for the environment.

In the South African context, where the Dutch Reformed Church became a symbolic place for the exclusion of black people - and be part of missionary strategies during the apartheid era - the notion of being an agent of God (missio $D e i)$ is in itself empowering for youth in the black townships and appreciating their own contribution in the service of the triune God. In collating voices from the majority world, Walls and Ross (2008) present five marks of contemporary mission including the aim to safeguard the integrity of creation. DeWitt (2008) responds, arguing that Christians' mission in terms of caring for creation can be found at the time of birth of all of creation. He states, 'With its beginnings in Eden, the mark was affirmed by God's convenant with every living creature (Genesis 9)...' (DeWitt 2008:84).

The nexus between black church youth regarding themselves as valuable cannot be divorced completely from other strategies for mission agents in terms of environmental carein terms of what have been discussed above. In the discussion on witnesses of God in mission, Ayre and Conradie (eds. 2016) argue that such witness can be through proclamation, worship, service and fellowship. Nevertheless, it is striking that in terms of service (diaconia) they state:
Others insist that one's deeds speak louder than one's words and therefore put the emphasis on service, that is, on helping the needy, on education, development projects, and so forth. (p. 8)

But then they add, 'The integrity of one person's lifestyle sets an example that others may want to follow' (:8). The last sentence brings into the centre the whole issue of personhood, and the development and appreciation of the self. This seems not to receive much emphasis by Ayre and Conradie (eds. 2016), but is crucially important for black church youth to become conscious of their worth, especially in the quest for a friendly environment.

In conclusion, one of the documents drafted on the African continent is the ACCRA confession (World Communion of Reformed Churches 1995). ${ }^{15}$ This confession is salient because it brings the empire today and the denial of life for all into conversation, especially in the context of the confession, the continued oppression and exploitation of people. This is a connection that should be taken seriously that while all life is important, the very lives of black people and particularly black youth have still been kept at the margins of the wealth of the countries. When the confession brings inequality and ecological destruction into conversation with each other, we are reminded of the black, church youth and their consciousness of the environment and its protection cannot be divorced from issues of inequality which would continue the 'self-hatred', the depreciation of black lives and its environment.

\section{Enroute to environmental consciousness through missional consciousness}

Therefore, the question at the end should be: How does the church play a role in black youth appreciating themselves? I suggest that this is where a 'missional consciousness' would play a crucial role. An awareness of mission and our contribution is because of God's first step - the initiator of mission (Bookless(2018). Bookless (2018:6) states, 'Mission actually starts in the heart of God'. In establishing this notion within the consciousness of black youth, they would be able to decouple mission from the church which has, as the institutional church, too much baggage of oppression, marginalisation and exclusion that often result in 'self-hatred'.

But secondly, God's mission is about God's Kingdom, and therefore God's rulership above all creation. It is Wright (2012; cf. Bookless 2018) who states that:

[T] he good news is not about sin or salvation in the Bible, but that Israel's God, the God of the Old Testament, becomes King of the whole world through the life, death and resurrection of Jesus. (p. 7)

Biko makes reference to this, within the missionary churches during apartheid that would focus on the inherent sinfulness

15.This confession was adopted in Ghana in 2004 , and was a response from the Reformed Family to the economic and environmental injustices of the global Reformed Family to the economic and environmental injustices of the global
economy on specifically third world countries. For more information on the Accra Confession, see the following website link http://wcrc.ch/accra. 
of people, but would specifically focus on black people and a denigration of their lives and culture and less of an appreciation of God in terms of black lives. If sermons and liturgy are crucial for creating an environmental consciousness, these should also be utilised to stress the importance of black lives within black communities cultivating an appreciation of black lives within the missio Dei. Therefore, Bookless' (2018) arguments seem to draw the line in the sand for a sermon on environmental care:

We are to preach and demonstrate the Lordship of Jesus Christ, and the liberation from all forms of oppression, sin, pollution and destruction that he proclaims, into every sphere of existence. (p. 7)

It is important for the churches in addressing the environmental degradation to also concentrate on God's love for all of creation, including all that is regarded as non-beings, and that the same attitude that eco-theologians warn humans about their relation to the earth, they should also emphasise the need to address relations between human beings - using the same logic as in the former case. Cone (2000) argues:

Why are their (white ecologists) essays and books about the endangered earth so monological - that is a conversation of a dominant group talking to itself? Why is there so much talk about love, humility, interrelatedness, and interdependence, and so little of these values reflected in white people's dealings with people of colour? (p. 44)

This is the gap that eco-theologians should still address more adequately.

\section{Conclusion}

As much as a black theological response is rendered to account for black youth and environmental degradation, it does not mean that critique cannot be launched to black theologians itself, which has not adequately responded to the issue of environmental care. In fact, most of its responses were indeed to the effect of the well-being of black people. However, this article is also an attempt to make a contribution from a black theological perspective on how to approach the issue of the consciousness of black church youth and their contribution towards environmental care. The idea that the author wishes to bring across in the article is to connect what the others have said about human beings' relation to the earth, and their relation to one another - but then specifically emphasised that in the South African context, this relationship (between one human being to another) cannot be articulated without a further qualification in ecological discourse. It has to address the ramifications of colonialism and apartheid within black 'souls' today if it wants to mobilise them towards addressing the ecological crisis.

I conclude with the statement of Cone (2000):

Only when white theologians realize that a fight against racism is a fight for their humanity will we be able to create a coalition of blacks, whites and other people of colour in the struggle to save the earth. Today ecology is in vogue and many people are talking about our endangered planet. I want to urge us to deepen our conversation by linking the earth's crisis to the human family. If it is important to save the habitats of birds and other species, then it is at least equally important to save black lives ... (p. 45)

The author therefore suggests a 'missional consciousness' for one of the strategies for black youth in the quest for the black youth's participation in environmental care.

\section{Acknowledgements Competing interests}

The author declares that he has no financial or personal relationships that may have inappropriately influenced him in writing this article.

\section{Author's contributions}

E.B. is the sole author of this article.

\section{Ethical considerations}

This article followed all ethical standards for research without direct contact with human or animal subjects.

\section{Funding information}

The author acknowledges the NRF for BAAP funding.

\section{Data availability}

Data sharing is not applicable to this article as no new data were created or analysed in this study.

\section{Disclaimer}

The views and opinions expressed in this article are those of the author and do not necessarily reflect the official policy or position of any affiliated agency of the author.

\section{References}

Ayre, C.W. \& Conradie, E.M. (eds.), 2016, The church in God's household: Protestant perspectives on Ecclesiology and ecology, Cluster Publications, Pietermaritzburg.

Baloyi, M.E., 2020, 'Black self-hatred: Regaining self-worth - From decolonisation towards reconciliation in South Africa - A practical theological appraisal', Theologia Viatorum 44(1), 1-8. https://doi.org/10.4102/tv.v44i1.33

Baron, E., 2017, 'The role of church youth in the transformation agenda of South African cities', HTS Teologiese Studies/Theological Studies 73(3), a4771. https:// doi.org/10.4102/hts.v73i3.4771

Baron, E., 2019, 'The call for African missional consciousness through renewed mission Praxis in URCSA', Journal Studia Historiae Ecclesiastiae 45(3), 19. https:// mission Praxis in URCSA', Journal Studi
doi.org/10.25159/2412-4265/6184

Bookless, D., 2018, 'Context or content? The place of the natural environment in world mission', in C. Ross \& C. Smith (eds.) Missional conversations: A dialogue between theory and praxis in world mission, pp. 3-15, SCM Press, London.

Bosch, D.J., 1991, Transforming mission: Paradigm shifts in theology of mission, Twentieth anniversary edition., Orbis Books, New York, NY.

Cone, J., 1997, God of the oppressed, Orbis Books, Maryknoll, NY.

Cone, J., 2000, 'Whose earth is it anyway?', CrossCurrents 50(1/2), 34-46.

Conradie, E.M., 2011, Christianity and earthkeeping: In search of an inspiring vision, Sun Press, Stellenbosch.

Delio, I., 2008, Care for Creation: A Franciscan spirituality of the earth, St. Anthony Messenger, Cincinnati, $\mathrm{OH}$.

DeWitt, C., 2008, 'To strive to safeguard the integrity of creation and sustain and renew the life of the earth', in A. Walls \& C. Ross (eds.), Mission in the 21st century: Exploring the five marks of global mission, pp. 84-93, Orbis Books, Maryknoll, NY. 
Elphick, R., 2012, The equality of believers: Protestant missionaries and the racial politics of South Africa, University of KwaZulu-Natal Press, Pietermaritzburg.

Fanon, F., 1990, Frantz Fanon: The wretched of the earth, transl. C. Farrington, Penguin Books, Cape Town

Ioannes, P.P. (John Paul) II, 1995, 'The gospel of life', Evangelium Vitae, viewed 01 August 2021, from https://www.vatican.va/content/john-paulii/en/encyclicals/ documents/hf_jp-ii_enc_25031995_evangelium-vitae.html.

Lei Win, T., 2020, 'How and why systemic racism harms the environment', Thomson Reuters Foundation News, viewed 27 March 2021, from https://news.trust.org/ Reuters Foundation News, viewec
item/20200813181850-kem2r.

Loader, J.A., 1991, 'Life, wonder and responsibility: Some thoughts on ecology and Christian mission', Missionalia 19(1), 44-56.

Maluleke, T., 2008, 'May the black God stand please! Biko's challenge to religion', in C. Du Toit (ed.), The Legacy of Stephen Bantu Biko, pp. 57-72, Unisa Press, Pretoria

Nche, G.C., Achunike, H.C. \& Okoli, A., 2017, 'Challenges of climate change and the culpability of churches: Towards an effective church climate change action in Nigeria', Missionalia 45(2), 168-187. https://doi.org/10.7832/45-2-183

Nel, R.W., 2015, 'Remixing interculturality, youth activism and Empire: A postcolonial theological perspective', Missionalia 43(3), 545-557. https://doi.org/10.7832/433-124

Nothwehr, D., 2015, 'The church's mission of ecojustice: A prophetic dialogue approach', in C. Ross \& S.B. Bevans (eds.), Mission on the road to Emmaus: Constants, context and prophetic dialogue, pp. 87-105, SCM, London.
Ramantswana, H., 2016, 'Decolonising biblical hermeneutics in the (South) African context', Acta Theologica 36(Suppl 24), 178-203.

Ross, A., 2018, 'Creation care around the world: Grounded engagement', in C. Ross \& C. Smith (eds.), Missional conversations: A dialogue between theory and praxis in world mission, pp. 16-24, SCM Press, London.

Smith, N., 2002, 'From Missio Dei to Missio Hominum: En route in Christian mission and missiology', in M. Karecki (ed.), The making of an African person: Essays in honour of Willem Saayman, pp. 4-21, South African Missiological Society, Pretoria.

Spencer, M.L., 2008, 'Environmental racism and black theology: James H. Cone instructs us on whiteness', University of St. Thomas Law Journal 5(1), 288-311.

Stubbs, A. (ed.), fl. 1978, I write what I like. Steve Biko: A selection of his writings, Heinemann Publishers, Oxford.

Tucker, M.E. \& Grim, J.M. (eds.), 2000, 'Foreword', in D.T. Hessel \& R.R. Ruether (eds.) Christianity and ecology: Seeking the well-being of earth and humans, pp. X-XIX, Harvard University Press, Cambridge.

Walls, A. \& Ross, C., 2008, Mission in the 21st century: Exploring the five marks of global mission, Orbis Books, Maryknoll, NY.

World Communion of Reformed Churches, 1995, Accra confession, WCRC, Germany.

Wright, N.T., 2012, How God became King: Getting to the heart of the gospels, SPCK, London. 